А.О. Литовченко ${ }^{1}$, В.В. Хижняк ${ }^{1}$, А.Г. Дмитрієв ${ }^{2}$

${ }^{1}$ Інститут державного управління у сфері ичивільного захисту, Київ

${ }^{2}$ Харківський національний університет Повітряних Сил ім. І. Кожедуба, Харків

\title{
АНАЛІЗ СКЛАДОВИХ ПОХИБОК ТРАЄКТОРНИХ ВИМІРЮВАНЬ НАТУРНИХ ВИПРОБУВАНЬ СКЛАДНИХ ТЕХНІЧНИХ ОБ'ЄКТІВ
}

За результатами аналізу похибок траєкторних вимірювань у зв'язку зі значною кількістю факторів, що впливають, а також для спрощення розрахунків і синтезу моделі похибок траєкторного комплексу показано, що похибка вимірювань $i$-го навігаџійного параметра $\xi_{i}$ (несучого інформацію про координати чи швидкість рухомого об'єкта) має нормальне розподілення і иілком характеризується значенням дисперсії похибок вимірювань.

Ключові слова: метрологічне забезпечення, траєкторні вимірювання, оцінка точносних характеристик.

\section{Вступ}

Постановка проблеми. Сучасні вимоги з точності і безпеці руху об'єктів, що переміщаються в повітряному, водному середовищі чи по земній поверхні визначають високий рівень точносних характеристик навігаційних комплексів цих об'єктів. Визначення точносних характеристик навігаційних комплексів і стану їхніх систем $є$ однією з основних задач при проведенні випробувань літальних апаратів, морських засобів, рухомої наземної техніки на спеціально обладнаних полігонах. Обладнання даних випробувальних полігонів містить собою сукупність вимірювальних систем, приладів і датчиків, що поєднуються у вимірювальні комплекси, за результатами застосування яких оцінюються параметри траєкторії об'єктів, які випробовуються. В процесі випробувань проводяться вимірювання координат фактичного місцезнаходження рухомого об'єкта за допомогою технічних засобів полігона, результати яких $є$ еталонними для оцінки точносних характеристик навігаційних комплексів, що випробовуються.

Параметри траєкторії будь-якого рухомого об'єкта можуть бути визначені двома методами [1-2]:

- методом прямого їх обчислення за допомогою геометричних співвідношень, коли вихідною інформацією є дальності, азимути чи курсові кути до точок з відомими координатами, а також висоти й азимути світил, що спостерігаються з об'єкта тощо;

- методом безупинного обчислення лінії руху (траєкторії) за даними про вектор швидкості і координати початкової точки руху.

Перший метод $€$ основним для випробувальних полігонів. Він реалізується технічними засобами, що працюють за принципами пасивної чи активної локації і вимірювань напрямку на об'єкти. Другий метод $€$ додатковим і грунтується на використанні доплерівських чи інерційних гіроскопічних систем.
Аналіз останніх досліджень та публікацій. Оснащення сучасних випробувальних полігонів технічними засобами проходило поетапно, з урахуванням постійно зростаючих вимог до технічного рівня зразків озброєння і військової техніки і їхніх характеристик. Паралельно з цим вирішувалася задача об'єднання технічних засобів у єдиний вимірювальний комплекс. Таким чином, вимірювальні комплекси сучасних випробувальних полігонів можна розглядати як багатопозиційні траєкторні вимірювальні комплекси. Такі багатопозиційні траєкторні вимірювальні комплекси містять собою унікальні технічні системи, що володіють такими особливостями:

- використанням тією чи іншою мірою просторово-часових методів обробки інформації, що закладена в навігаційних полях і траєкторних сигналах, прийнятих одночасно в просторово-рознесених точках прийому (у тому числі рухомих) з використанням як активних, так і пасивних методів прийому сигналу;

- високої (на рівні еталонної) точності оцінки траєкторій об'єктів;

- необмеженими (нарощуваними в міру ускладнення) робочими зонами;

- наявністю вимірювальних засобів, різних як за технічним станом, так і за точносними характеристиками.

Теоретичну основу побудови і застосування таких багатопозиційних траєкторних вимірювальних комплексів складає теорія оптимальної лінійної $\mathrm{i}$ нелінійної фільтрації умовних марковських процесів $[3-4 ; 5]$. В той же час питання, що пов'язані з оцінкою точносних характеристик багатопозиційних вимірювальних комплексів траєкторних вимірювань залишаються малодослідженими. Це суттєво позначається на термінах і вартості випробувань та доведення нових технічних об'єктів до серійного зразка. 
Метою статті $\epsilon$ визначення складових похибок при проведенні траєкторних вимірювань натурних випробувань складних технічних об'єктів.

\section{Виклад основного матеріалу}

Ефективне вирішення проблеми метрологічної атестації багатопозиційних вимірювальних комплексів траєкторних вимірювань за умови виконання сучасних вимог може бути досягнуто тільки за допомогою методики комплексної оцінки точності, яка грунтується на спільному використанні розрахункових методів, моделювання й експериментальних досліджень [6-8]. Основою комплексної методики є використання моделі точносних характеристик багатопозиційного вимірювального комплексу траєкторних вимірювань (далі - траєкторного комплексу), яка послідовно уточнюється. Для вибору виду базової моделі точносних характеристик комплексу не- обхідно:

- провести розподіл сумарних похибок на складові;

- визначити фактори, що збуджують ті чи інші складові похибок, виявити систематичні складові.

Проведений аналіз показує, що траєкторні комплекси, як об'єкти досліджень, являють собою структурно складні інформаційно-вимірювальні системи, точносні характеристики яких залежать від низки факторів і характеризуються просторово-часовою змінністю. Сумарна середньоквадратична похибка визначення параметрів траєкторії рухомого об'єкта залежить від безлічі функціонально залежних факторів, повне урахування яких навряд чи можливе. Складові похибок, обумовлені цими факторами, можна об'єднати в такі три великі групи: апаратурні похибки, похибки моделі, методичні похибки (рис. 1).

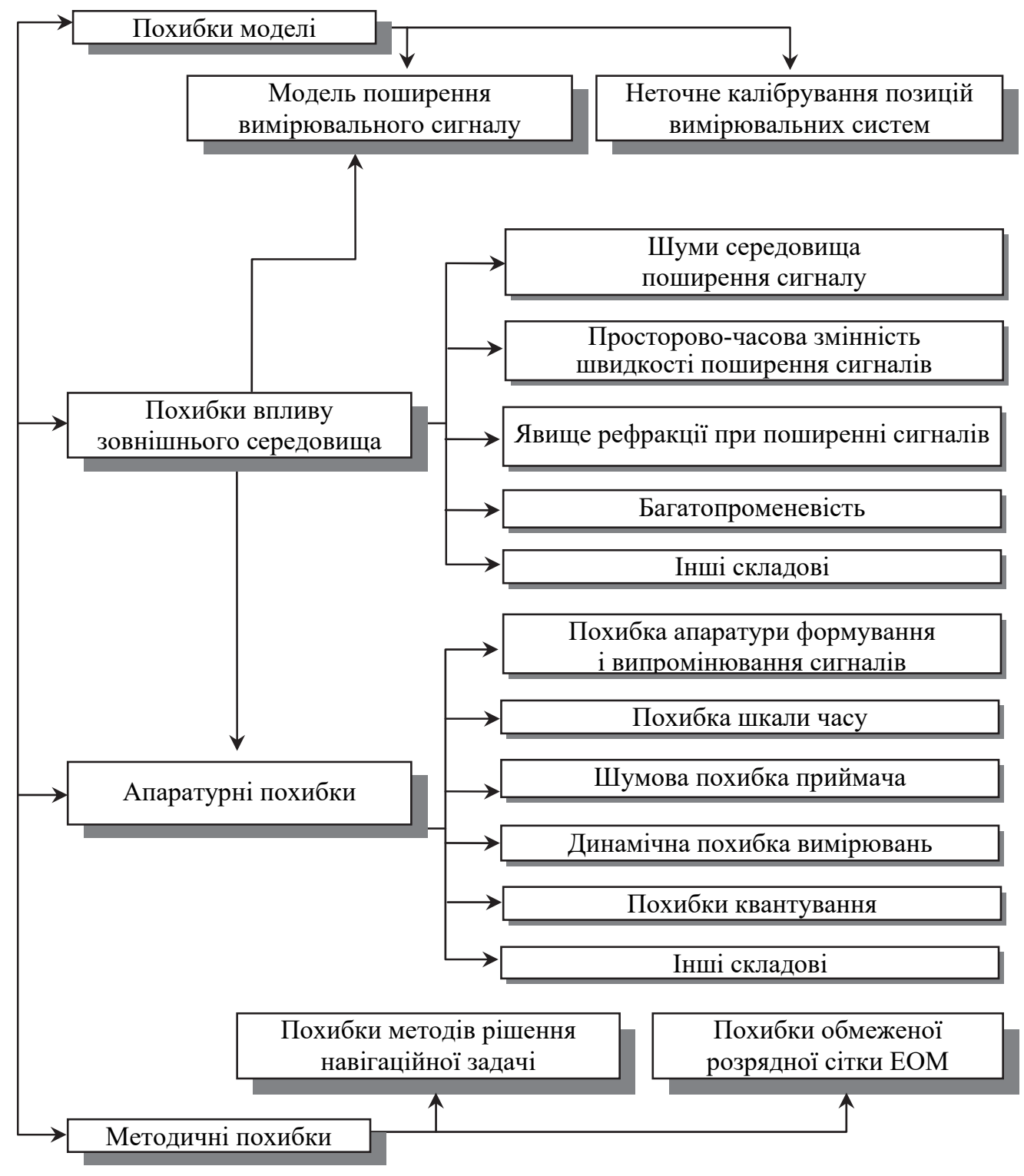

Рис. 1. Класифікація похибок полігонних систем визначення параметрів траєкторії рухомих об’єктів 
Апаратурна похибка визначається інструментальними похибками (безпосередньо пов'язаними 3 конструкцією вимірювальних систем) і сумісним впливом похибок апаратури, що вносяться зовнішнім середовищем

Похибки, внесені зовнішнім середовищем, різноманітні за своїм походженням і ступенем впливу для різних типів траєкторних комплексів.
Джерелами цих похибок $є$ зовнішні завади, змінні умови поширення навігаційних сигналів, коливання температури, вологості, напруги живлення тощо. На рис. 2 представлено варіант структурної схеми каналу розповсюдження навігаційного сигналу (для метода пасивної локації), що пояснює спільну дію перерахованих впливаючих факторів [9].

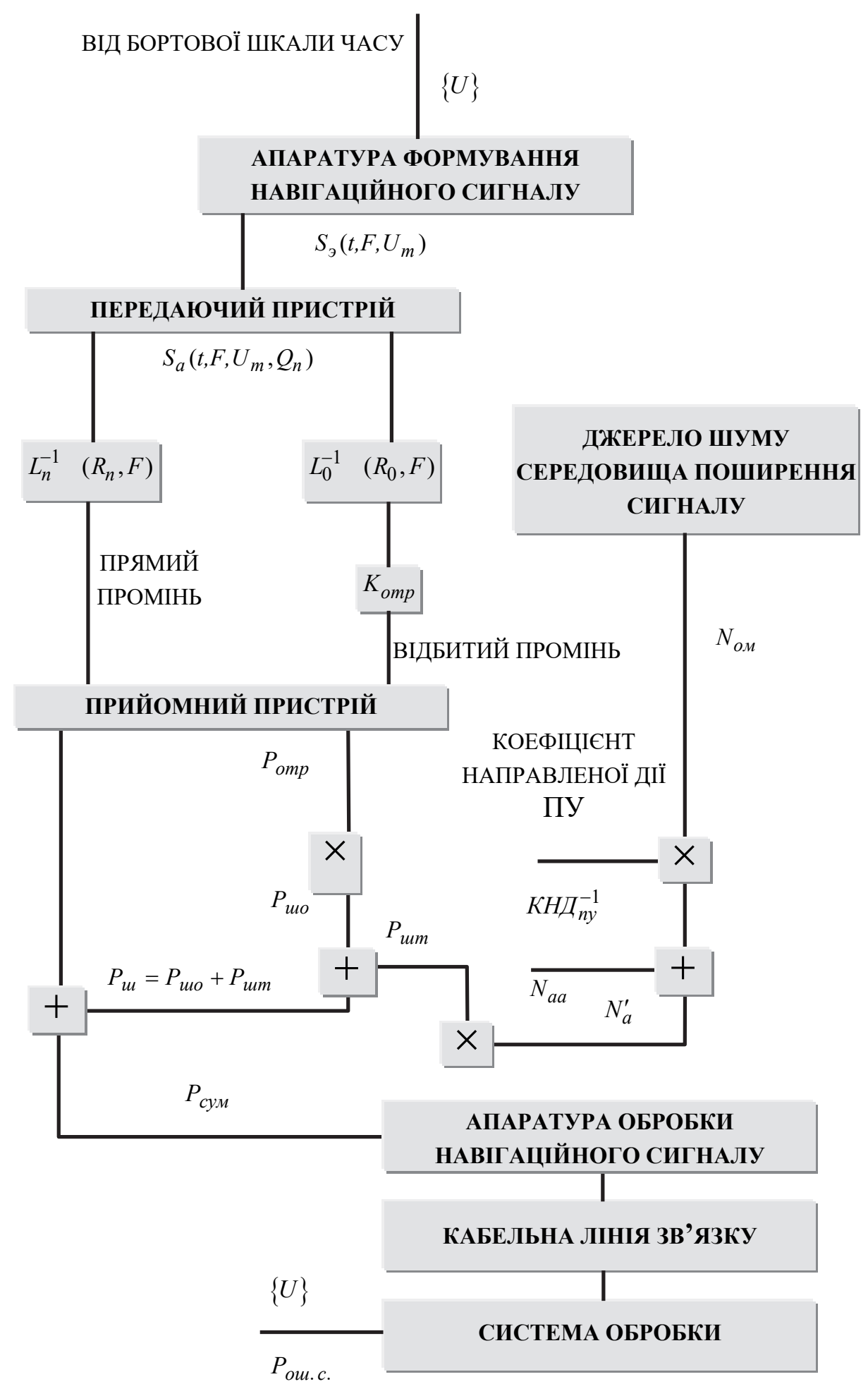

Рис. 2. Структурна схема каналу поширення сигналу пасивної локації 
На схемі приведені функціональні зв'язки між елементами каналу, показана прив'язка цих елементів до технічних підсистем траєкторного комплексу, розкрита двопроменева структура каналу. На схемі позначено:

$S_{\ni}\left(t, F, U_{m}\right)$ - сигнал, сформований бортовою підсистемою, що встановлена на рухомому об'єкті й утримуючий інформацію про бортовий час $t$;

$S_{a}\left(t, F, U_{m}, Q_{n}\right)$ - сигнал на виході передавальної системи 3 частотою $F$, характеристиками модуляції $U_{m}$ і просторовими характеристиками випромінюючої антени $Q_{n}$;

Ршо і Ршт - приведені потужності прийнятого сигналу по відбитому променю і шумовому сигналу, відповідно, з урахуванням коефіцієнта спрямованості прийомної антени. Методичні похибки визначення координат рухомого об'єкта визначаються припущеннями i наближеннями при обгрунтуванні принципу дії системи і розрахунку її характеристик,

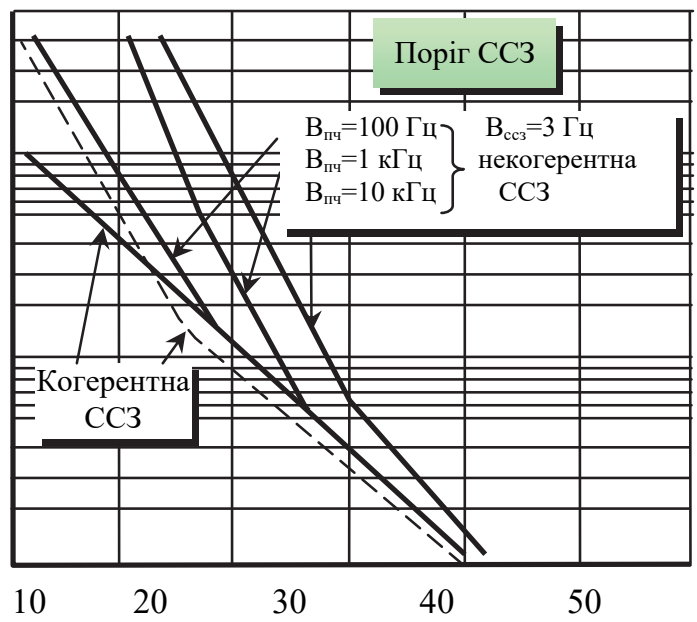

Рис. 3. Залежність апаратурної похибки системи слідкування за затримкою сигналу з псевдошумовим кодом від відношення сигнал/шум на вході вимірювального пристрою

\section{Висновок}

Через значну кількість факторів, що впливають, а також для спрощення розрахунків і синтезу моделі похибок траєкторного комплексу можна вважати, що похибка вимірювань $i$-го навігаційного параметра $\xi i$ (несучого інформацію про координати чи швидкість рухомого об'єкта), відповідно до центральної граничної теореми має нормальне розподілення i цілком характеризується значенням дисперсії $\sigma_{i}^{2}(t)$ похибок вимірювань [11-13]. а також похибками обчислювального процесу. Джерелами похибок обчислювального процесу у вимірювальних системах траєкторних комплексів є обмежена розрядна сітка процесора, математичні апроксимації і наближення, виконання команд із часовою затримкою.

Похибки моделі траєкторних комплексів визначаються, в основному, похибками прив'язки технічних систем, відносно яких проводяться вимірювання навігаційних параметрів, та похибками моделей поширення сигналів.

Вплив кожної з перерахованих вище складових визначається технічними рішеннями, закладеними в конкретні системи, які працюють у повітряному чи водному середовищі і реалізують різні способи вимірювань навігаційних параметрів. Як приклади на рис. 3 , рис. 4 приведені результати моделювання, що показують вплив складових похибок для конкретних систем [10].

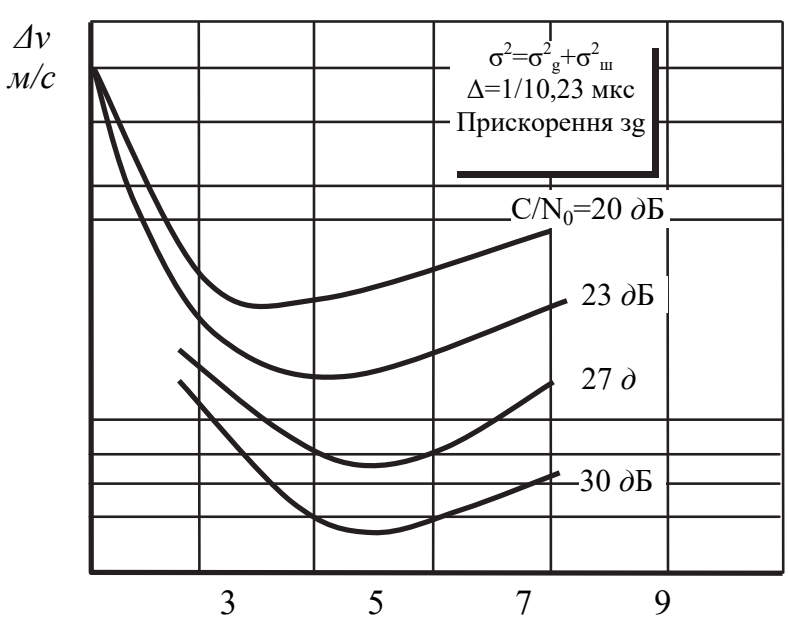

Рис. 4. Нормована похибка системи слідкування за затримкою сигналу псевдошумовим кодом, що обумовлена динамікою об’єкту і шумом

Зазвичай $\sigma_{i}^{2}(t)$, так само як і параметр $\xi i$, що вимірюється, є функцією часу. При цьому значення $\sigma_{i}^{2}(t)$ може бути розраховане для кожної вимірювальної системи, що входить до складу полігонного комплексу за відомими формулами з урахуванням ступеня впливу складових похибок. Сукупність значень $\sigma_{i}^{2}(t)$ для складових систем вимірювального комплексу є вихідною інформацією для оцінки його точносних характеристик у цілому.

\section{Список літератури}

1. Бабич О.А. Обработка информации в навигационных комплексах / О.А. Бабич. - М.: Машиностроение, 1991. -512 с.

2. Литовченко А.О. Рішення задачі оптимального управління метрологічним забезпеченням випробувань складних технічних об’єктів / А.О. Литовченко, В.В. Хижняк // Матеріали 19-ї Всеукраїнської науково-практичної конференції рятувальників. - Київ, 11-14 жовтня 2017 р. - С. 454-456. 
3. Кондратьев В.С. Многопозиционные радиотехнические системы / В.С. Кондратьев, А.Ф. Котов, Л.Н. Марков. М.: Радио и связь, 1986. -264 с.

4. Стратонович Р.Л. Применение теории процессов Маркова для оптимальной фильтрации сигналов / Р.Л. Стратонович // Радиотехника и электроника. - 1960. - Т. 5, № 11. - С. 121-125.

5. Ярлыков М.С. Статистическая теория радионавигации. - М.: Радио и связь, 1985. -344 с.

6. Железнов И.Г. Сложные технические системы (оценка характеристик). - М.: Высшая школа, 1984. -119 с.

7. Литовченко А.О. Аналіз методів прогнозування технічного стану складних систем та особливості їх застосування при формуванні програм експлуатації державних еталонів / А.О. Литовченко, А.Г. Дмитрієв, В.В. Хижняк // Системи озброєння і військова техніка. - 2016. - № 4(48), С. 57-60.

8. Литовченко А.О. Оцінка якості технічних і метрологічних характеритик аналітичних ймовірнісних інформаційно-вимірювальних систем за результатами моделювання / А.О. Литовченко, А.Г. Дмитрієв, В.В. Хижняк // Збірник наукових праць Харківського національного університету Повітряних Сил. - 2018. - № 4(58), С. 101-107.

9. Лётные испытания пилотажно-навигационных комплексов самолётов и вертолётов / Е.Г. Харин, О.В. Виноградов, А.Л. Аваев и др. - М.: Машиностроение, 1985. - 128 с.

10. Хижняк В.В. Обгрунтування можливих варіантів створення полігонної системи траєкторних вимірювань на базі приймачів сигналів супутникових навігаційних систем / В.В. Хижняк // Радіоелектронні і комп’ютерні системи. - 2003. № 4(4). - С. 176-182.

11. Манохин А.Е. Аттестация испытательного оборудования / А.Е. Манохин, Э.П. Шмидт, А.С. Вишенков. - М.: Машиностроение, 1985. - 63 с.

12. Белавин О.В. Основы радионавигации / О.В. Белавин. - М.: Советское радио, 1977. - 320 с.

13. Радиотехнические системы / Ю.П. Гришин, В.П. Платов, Ю.М. Казаринов и др. - М.: Высшая, школа, 1990. $303 \mathrm{c}$.

\section{References}

1. Babych, O.A. (1991), “Obrabotka ynformatsyy v navyhatsyonnykh kompleksakh" [Information processing in navigation systems], Mashynostroenye, Moscow, $512 \mathrm{p}$.

2. Lytovchenko, A.O. and Khyzhniak, V.V. (2017), "Rishennia zadachi optymalnoho upravlinnia metrolohichnym zabezpechenniam vyprobuvan skladnykh tekhnichnykh ob'iektiv" [Solution to the problem of optimal management of metrological testing of complex technical objects], Proceedings of the XIXth All-Ukrainian Researchers' Conference, 11-14 October, Kyiv, pp. 454-456.

3. Kondratev, B.C., Kotov, A.F. and Markov, L.N. (1986), "Mnohopozytsyonnye radyotekhnycheskye systemy" [Multipoint radio engineering systems], Radyo y sviaz, Moscow, $264 \mathrm{p}$.

4. Stratonovych, R.L. (1960), "Prymenenye teoryy protsessov Markova dlia optymalnoi fyltratsyy syhnalov" [Application of Markov process theory for optimal signal filtering] Radyotekhnyka y elektronyka, Vol. 5, No. 11, pp. 121-125.

5. Yarlykov, M.S. (1985), "Statystycheskaia teoryia radyonavyhatsyy" [Statistical theory of radio navigation], Radyo y sviaz, Moscow, 344 p.

6. Zheleznov, Y.H. (1984), "Slozhnie tekhnycheskye systemy (otsenka kharakterystyk)" [Complex technical systems (performance evaluation)], Vysshaia shkola, Moscow, $119 \mathrm{p}$.

7. Lytovchenko, A.O., Dmytriiev, A.H. and Khyzhniak, V.V. (2016), "Analiz metodiv prohnozuvannia tekhnichnoho stanu skladnykh system ta osoblyvosti yikh zastosuvannia pry formuvanni prohram ekspluatatsii derzhavnykh etaloniv" [Analysis of methods of forecasting the technical state of complex systems and features of their application in the formation of programs of operation of state standards], Systems of Arms and Military Equipment, No. 4(48), pp. 57-60.

8. Lytovchenko, A.O., Dmytriiev, A.H. and Khyzhniak, V.V. (2018), "Otsinka yakosti tekhnichnykh i metrolohichnykh kharakterytyk analitychnykh ymovirnisnykh informatsiino-vymiriuvalnykh system za rezultatamy modeliuvannia” [Quality assessment of technical and metrological characteristics of analytical probabilistic information-measuring systems based on simulation results], Scientific Works of Kharkiv National Air Force University, No. 4(58), pp. 101-107.

9. Kharyn, E.H., Vynohradov, O.V. and Avaev, A.L. (1985), "Lytnie yspytanyia pylotazhno-navyhatsyonnykh kompleksov samolyotov y vertolyotov" [Flight tests of flight and navigation complexes of airplanes and helicopters], Mashynostroenye, Moscow, $128 \mathrm{p}$.

10. Khyzhniak, V.V. (2003), "Obgruntuvannia mozhlyvykh variantiv stvorennia polihonnoi systemy traiektornykh vymiriuvan na bazi pryimachiv syhnaliv suputnykovykh navihatsiinykh system" [Substantiation of possible variants of creation of polygonal system of trajectory measurements on the basis of receivers of signals of satellite navigation systems], Electronic and Computer Systems, No. 4(4), pp. 176-182.

11. Manokhyn, A.E., Shmydt, Ye.P. and Vyshenkov, A.S. (1985), "Attestatsyia yspbitatelnoho oborudovanyia" [Certification of testing equipment], Mashynostroenye, Moscow, $63 \mathrm{p}$.

12. Belavyn, O.V. (1977), “Osnovy radyonavyhatsyy" [Basics of radio navigation], Sovetskoe radyo, Moscow, 320 p.

13. Hryshyn, Yu.P., Platov, V.P. and Kazarynov, Yu.M. (1990), "Radyotekhnycheskye systemy" [Radio engineering systems], Vysshaia shkola, Moscow, $303 \mathrm{p}$. 
Відомості про авторів:

Литовченко Анастасія Олександрівна

викладач кафедри

Інституту державного

управління у сфері цивільного захисту,

Київ, Україна,

https://orcid.org/0000-0002-6696-8255

Хижняк Володимир Віталійович

кандидат технічних наук старший науковий співробітник завідувач кафедри

Інституту державного управління в сфері

цивільного захисту,

Київ, Україна

https://orcid.org/0000-0003-0437-749X

\section{Дмитрісв Андрій Геннадійович}

кандидат технічних наук старший науковий співробітник старший науковий співробітник

Харківського національного університету

Повітряних Сил ім. I. Кожедуба,

Харків, Україна

https://orcid.org/ 0000-0002-8710-5598

\section{Information about the authors:}

\author{
Anastasiia Lytovchenko \\ Instructor of Department \\ of the Institute of Public Administration \\ in the Field of Civil Protection, \\ Kyiv, Ukraine \\ https://orcid.org/0000-0002-6696-8255
}

Volodymyr Khyzhniak

Candidate of Technical Sciences Senior Research

Head of the Department

of Institute of Public Administration

in the Sphere of Civil Protection,

Kyiv, Ukraine

https://orcid.org/0000-0003-0437-749X

\section{Andrii Dmytriiev}

Candidate of Technical Sciences Senior Research

Senior Research Associate

of Ivan Kozhedub Kharkiv

National Air Force University,

Kharkiv, Ukraine

https://orcid.org/ 0000-0002-8710-5598

\title{
АНАЛИЗ СОСТАВЛЯЮЩИХ ПОГРЕШНОСТЕЙ ТРАЕКТОРНЫХ ИЗМЕРЕНИЙ НАТУРНЫХ ИСПЫТАНИЙ СЛОЖНЫХ ТЕХНИЧЕСКИХ ОБЪЕКТОВ
}

А.О. Литовченко, В.В. Хижняк, А.Г. Дмитриев

По результатам анализа погрешностей траекторных измерений в связи с большим количеством влияюших факторов, а также для упрощения расчетов и синтеза модели погрешностей траекторного комплекса выявлено, что погрешность измерений і-го навигационного параметра 乌і (несущего информацию о координатах или скорости подвижного объекта) имеет нормальное распределение и вполне характеризуется значением дисперсии погрешностей измерений.

Ключевые слова: метрологическое обеспечение, траекторные измерения, оценка точносных характеристик.

\section{ANALYSIS OF COMPONENT ERRORS OF TRACTOR MEASUREMENTS OF NATURAL TESTS OF COMPLEX TECHNICAL OBJECTS}

\author{
A. Lytovchenko, V. Khyzhniak, A. Dmytriiev
}

Effective solution of the problem of metrological certification of multi-position measuring complexes of trajectory measurements, provided the modern requirements can be achieved only with the help of complex accuracy estimation, which is based on the shared use of calculation methods, modeling and experimental studies. The analysis shows that trajectory complexes, as objects of research, are structurally complex information-measuring systems, the exact characteristics of which depend on a number of factors and are characterized by spatio-temporal variability. The total standard error of determining the parameters of the trajectory of a moving object depends on many functionally dependent factors, a complete account of which is hardly possible. The components of the errors caused by these factors can be grouped into the following three large groups: hardware errors, model errors, methodological errors. Instrumental error is determined by instrumental errors (directly related to the design of measurement systems) and the combined effect of instrumental errors made by the external environment. The environmental errors are diverse in origin and degree of impact for different types of trajectory complexes. The errors of the model of trajectory complexes are determined mainly by the errors of the binding of the technical systems, relative to which measurements of navigation parameters are made, and the errors of the models of signal propagation. The impact of each of the above components is determined by the technical solutions embedded in specific systems that operate in the air or water environment and implement different methods of measuring navigation parameters. The results of the analysis of the errors of the trajectory measurements due to the large number of influencing factors, as well as to simplify the calculations and synthesis of the model errors of the trajectory complex showed that the measurement error of the $i$-th navigation parameter $\xi i$ (carrying coordinate information or velocity of the moving object) has a normal distribution and is fully characterized by the value of the variance of measurement errors.

Keywords: metrological support, trajectory measurements, estimation of precision characteristics. 